\title{
EXECUTIVE FUNCTION ROLE ON A STAGE OF IMPASSE IN INSIGHT PROBLEM SOLVING
}

\author{
P.N. MARKINA ${ }^{\mathrm{a}, \mathrm{b}}$, I.YU. VLADIMIROV ${ }^{\mathrm{a}}$ \\ ${ }^{a}$ Yaroslavl Demidov State University, 14 Sovetskaya Str., Yaroslavl, 150000, Russian Federation \\ ${ }^{b}$ Institute of Psychology, Russian Academy of Sciences, 13 build. 1, Yaroslavskaya Str., Moscow, 129366, \\ Russian Federation
}

\begin{abstract}
The paper is focused on the role of a central executive in insight and non-insight problem solving. The central Executive (CE) is responsible for planning for problem solving, and comparing the current situation with a desired one. It is assumed that the Central Executive is harmful at the stage of an impasse in insight problem solving. The CE fixates the solver on a wrong representation. Contrariwise, the $\mathrm{CE}$ is important in non-insight problem solving throughout the solution time. We used the distraction method, which involves the presentation of an additional task during whilst solving the main problem. Due to that we deplete the Central Executive by overloading. We suppose the Central Executive can't perform well doing two problems at the same time, consequently, we provided our participants with the second task, which they solved simultaneously with the main problem. The results of the experiment made it possible to confirm the assumption of a changing role of the $\mathrm{CE}$ during insight problem solving: the depletion of the $\mathrm{CE}$ is important only at the impasse stage to give the solver an opportunity to take into account the elements of the problem that are irrelevant to the primary representation. Out of the impasse control is needed to solve problems: prior to reaching the impasse, the Central Executive is needed to complete search for all obvious solutions; after breaking out of the impasse the $\mathrm{CE}$ is responsible for the choice of the best answer from a new list. It is concluded that at the stage of the impasse control hinders solving insight problems.
\end{abstract}

Keywords: insight, insight problem solving, impasse, Central Executive.

\section{Introduction}

Insight problem solving is one of the most debatable phenomena in the psychology of thinking. Despite the long history of investigating this phenomenon, there was no consensus among researchers regarding insight problem solving specifics in

The reported study was funded by the government contract No 25.5666.2017/8.9 and RFBR according to the research project № 17-06-00672. 
comparison to non-insight problem solving. To some extent insight and noninsight problems are solved in a similar way, however there are significant differences in the progress of auxiliary information processes: the stages of problem solving, mechanisms and conditions that help and hinder the solution of insight and non-insight problems vary considerably.

One of the auxiliary processes involved in solving insight problems is working memory (WM) (Baddeley, 2003). WM preserves the initial conditions of a task, intermediates actions and solutions, monitors the progress of the solution and compares the current representation with the requirements of the task as well (Ibid.). In order to analyze the specifics of insight problem solving, we focus on the particular component of working memory - the central control unit or central executive (CE). This part of working memory implements planning and the ability to set goals and strive for them. These functions are crucial to successfully solve both types of problems - insight or non-insight. However, the central executive can affect the problem solving process in different ways depending on the type of problem. Non-insight problems require a predefined plan of action, and it is necessary to consider preliminary results when moving from one action to another. The CE plays a major role in the step-by-step process of finding a solution. Some researchers pay attention to the $\mathrm{CE}$ role in solving various mental tasks, due to its ability to limit the amount of attention, as well as to distribute attention and regulate the attention switching. All these functions determine the algorithm and the way of solving problems (Machinskaya, 2015). In experiments of K. Gilhooly and his team it was observed that problem solving accompanied by depleting resources of the CE leads to poorer performance in solving syllogistic-reasoning tasks (Gilhooly, Logie, Wetherick, \& Wynn, 1993). Robbins and colleges also demonstrated that loading of the CE disrupted solving chess problems (Robbins et al., 1996).

Although there is no general consensus on the role the CE plays in insight problem solving, some researchers suggest that the $\mathrm{CE}$ is also significant to the process of solving insight tasks. In the experiments of Lavric and colleagues it was shown that insight problem solving requires less CE load compared to non-insight problem solving. The one of the assumptive distinctive features of insight problem solving is diminished conscious control over the solution process (Jarosz, Colflesh, \& Wiley, 2010). Thus, in their research Jarosz and co-authors looked into the facilitating influence of moderate alcohol intoxication on the problem solving performance. In the absence of distraction the CE makes it possible to accurately identify and screen out those elements of the problem that are irrelevant to the solution.

Although this function is essential for non-insight problems, it hampers the solution of insight problems, due to the obscurity of relevance of each element of the problem at the moment of the problem presentation. Alcohol affects the CE reducing its effectiveness in a way that more information remains in the focus of attention, allowing for the necessary element to be included in a new representation of the problem that will bring the solver to the correct solution. In other words, solutions to insight problems are not situated in the presupposed problem space, so a degraded selection of information and a reduced level of control may lead to a faster and more correct answer. 
The negative influence of the central executive on insight problem solving was also empirically proved by Reverberi and his colleagues. The central executive unit is supposedly associated with the functioning of the prefrontal cortex, especially its dorsolateral part. Accordingly, patients with the dysfunctional lateral frontal cortex are unable to use the functions of the CE. The researchers have proved that such patients are better than participants without deficit at coping with insight matchsticks problems. Hence, the CE has a negative influence on the ability to solve insight problems (Reverberi, Toraldo, D'Agostini, \& Skrap, 2005).

Another possible explanation for the detrimental effect of the CE on insight problem solving is based on the structure of the solving process. In particular, the abundance of the CE forces the solver to be stuck in the impasse stage where one has to reject wrong or obvious solutions in order to be able to discover the right one. Moreover, some researchers argue that overcoming an impasse is critical for insight problem solving (Ohlsson, 1992). Therefore, the lack of the CE at the impasse stage might improve insight problem solving.

In the process of overcoming the impasse, the representation of the problem changes: the solver moves from the past wrong representation of the problem to the new right one, in which the contradictions that previously had led to the impasse were resolved and the problem has a solution. However, it is not clear how exactly this change of the representation proceeds and what mechanisms are responsible for it. We assume it is important to reject the old representation, the integrity of that is supported by the CE. Therefore, the disabling of this structure should help the solver to change the representation and quickly proceed to the correct solution of the problem.

Hypothesis. Based on the mentioned literature we assume, that it is possible to disable the CE by "overloading" it due to its limited resources. Potentially, the overwhelming amount of problems might deplete resources of the CE and lead to its attenuation. Since weakening the CE might improve insight problem solving, we hypothesized that the depletion of cognitive monitoring at certain stages of the process will reduce the time to reach the solution in insight problems.

Operational hypotheses: We assumed that the role of the central executive varies at different stages in insight problem solving. The CE is most harmful at the stage of impasse as it does not allow the problem to refuse a wrong solution plan. Therefore, we come to the following hypotheses:

Hypothesis 1. Depletion of the CE at any stage has a negative effect on the process of non-insight problem solving.

Hypothesis 2. Depletion of the CE at the impasse stage has a positive effect on the process of insight problem solving.

Hypothesis 3. Depletion of the CE before or after the impasse stage does not affect the process of insight problem solving.

\section{Method}

In our research we used an interruption paradigm in order to overwhelm the CE. We asked participants to begin solving an insight or non-insight problem. 
After 10 or 20 seconds (depending on the conditions) we presented participants with an additional problem asking them to switch their resources to the new one. When the additional problem was solved, we asked participants to continue working on the main problem they had started to solve at the beginning of the experiment.

We assumed that the CE would not be able to process two problems simultaneously and for a while - when the first problem is already loaded in the WM and the second task is presented - the $\mathrm{CE}$ will be weakened. Correspondingly, disabling the $\mathrm{CE}$ would speed up the process of finding the solution for the main problem.

The results of the pilot experiment showed that the solution of the problems we chose as a stimuli takes on average 60 seconds to solve; based on this, we assumed that the impasse occurs in the first 10-20 seconds. For 10 seconds participants were able to read, understand the problem and be confronted by its difficulties. The purpose of our experimental influence was to prevent participants from getting into an impasse. According to our assumptions, the impasse stage happens as soon as the solver understands that insight problem solving requires finding an unobvious solution unlike the non-insight one. The interval of 20 seconds then would fall specifically on the insightful stage of the solution and would not coincide with the impasse.

We used matchsticks problems as stimuli. This type of problems is well-suited for investigating insight problem solving, due to the variety of these problems, the possibility to equalize their complexity and the presence of non-insight problems based on the same material. In order to find the answer, one has to correct an equation written in Roman numerals (Knoblich, Ohlsson, Haider, \& Rhenius, 1999; Wong, 2009). This class of problems has the following subcategories: A - to make the equation correct, a matchstick should be moved from one number to another; $\mathrm{B}$ - the matchstick moves from the arithmetic symbol to a number and vice versa; and $\mathrm{C}-\mathrm{V}$ should be turned into $\mathrm{X}$ and vice versa.

\section{Participants}

44 people participated in the experiment (mean age of participants was 36 years, $\mathrm{SD}=11.2,25$ women, 19 men).

\section{Design}

In the experimental group 20 participants solved 8 problems: 2 insight problems of type A, 2 insight problems of type B, 2 insight problems of type C and 2 noninsight problems. The order of the stimuli presentation was randomized. After 10 or 20 seconds the solving was interrupted by presenting participants with one of eight additional tasks of two types: an algebraic problem or a spatial problem with matchsticks. All additional tasks were laid out of matchsticks so that participants could easily switch from main task and an additional one. Additional algebraic problems were written in Roman numerals, like the main problems. Another type of additional tasks was presented by problems where it was necessary to rearrange 
the matchsticks so the composition would change according to the statement of the problem. Time of interruption was empirically controlled as well as the type of the primary and secondary tasks. Another 24 participants were randomly assigned into the control group. They solved the same 8 problems without an interruption. We measured the solving time for each problem. However, we didn't measure the time it took to solve the additional problems. For the sake of convenience, we present only data of the comparison between non-insight and insight problems.

\section{Results}

In accordance with the hypotheses, we considered the influence of interruption on the central executive functioning in insight and non-insight problem solving.

First, we calculated the two-way ANOVA, where the independent variable was the time or presence of interruption and the type of the main problem (insight or non-insight); the dependent variable was the problem solving time. Analysis of the interaction of the problem type and time of the interruption didn't reveal any significant results $\left(F(2,198)=2.78, p=.065, \eta_{p}^{2}=0.028\right)$. The problem type didn't affect the time of solving as well $\left(F(1,198)=0.171, p=.68, \eta_{p}^{2}=0.01\right)$. However, the time of interruption did affect the problem solving time $(F(2,198)=18.68, p<.001$, $\left.\eta_{p}^{2}=0.16\right)$ The results are presented with the post-hoc Bonferroni test. The data is presented in Figure 1.

The values of the Levene's test are significant due to the difference in the variance over time in solving insight and non-insight problems. Therefore, only the interruption factor was statistically significant. In order to clarify the results we compared the solution time separately for the types of problems: insight and non-insight.

One-way ANOVA revealed that interruption also significantly influenced the solving time of insight problems $\left(F(2,92)=7.22, p=.001, \eta_{p}^{2}=0.111\right)$. Since the

Table 1

The Effect of an Interrupt and the Type of Problem on the Solution Time

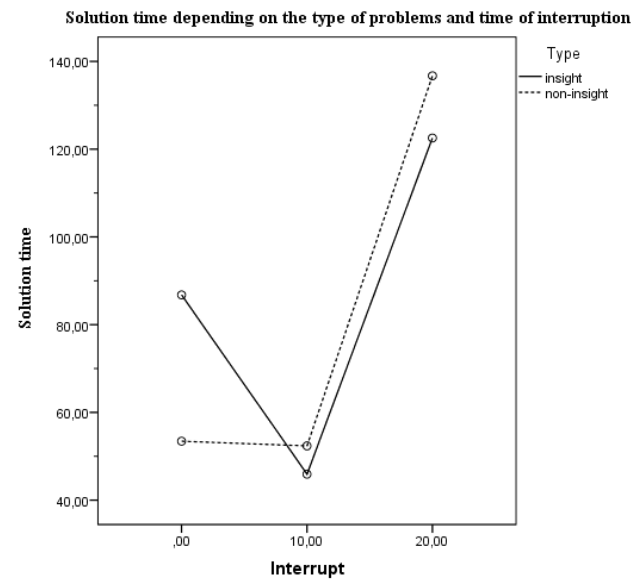


values of the Levene's test are significant, we verified the results by the Welch statistics $(F(2,92)=16.01, p<.001)$.

In this type of problems pairwise comparison showed that solving time when interrupted after 10 seconds insight problems and uninterrupted solutions of insight problems significantly differs $\left(F(1,66)=6.63, p=.012, \eta_{p}^{2}=0.068\right)$. Solution time when interrupted after 10 seconds and solution time when interrupted after 20 seconds also significantly differ $\left(F(1,52)=20.31, p<.001, \eta_{p}{ }^{2}=0.285\right)$ The difference between uninterrupted solutions and interrupted after 20 seconds is also insignificant $\left(F(1,65)=3.47, p=.066, \eta_{p}^{2}=0.037\right)$.

In general, the factor of solution interruption is significant. In non-insight problems, the time increases significantly if the solution was interrupted after $20 \mathrm{sec}-$ onds from the start. In insight problems, the solution time is significantly decreased if their solution was interrupted 10 seconds after the solution was initiated.

\section{Discussion}

We hypothesized that the interruption at any stage has a negative influence on the solution of non-insight problems. Based on the obtained data, we can not completely reject or confirm this hypothesis, since the interruption after 10 seconds after the beginning of the solution does not have a statistically significant effect on the problem solving time. We suppose that this is due to the fact that the solver's working memory allows them to remember how many arithmetic operations they have already done and they can save the preliminary result of the problem. Hence, on returning to the solution the person continues to solve the problem from the place where their solution was interrupted. Therefore the time of the problem solving with interruption after 10 seconds is identical to the solution time without interruption. However, the interruption after 20 seconds significantly increases the solution time for non-insight problems. This might be explained by the fact that participants forgot the preliminary result of the solution, and they had to recalculate the problem anew.

Our second hypothesis was that interrupting the solution of insight problems at the impasse stage has a positive effect on the process of insight problem solving. The obtained data make us accept this hypothesis, assuming that after 10 seconds the solver falls into the impasse when solving insight problems with matchsticks

In the last hypothesis, we assumed that the disruption of the $\mathrm{CE}$ out of the impasse stage does not affect the process of insight problem solving. Assuming that most solvers are not in the impasse after 20 seconds of the solution, we are inclined to accept this hypothesis as well.

For insight problems, the impact of the central executive has several aspects. It is important to deplete the $\mathrm{CE}$ only at the stage of the impasse to give the solver an opportunity to take into account the elements of the problem that are irrelevant to the primary representation. On the other hand, such elements might be necessary for the subsequent solution. Prior to reaching the impasse, the $\mathrm{CE}$ is required to do a complete search for all obvious solutions; after breaking out of the impasse the $\mathrm{CE}$ is responsible for the choice of the best answer from the new list. If its impact 
is diminished at this point, the solver risks to choose a wrong answer or spend more time finding the solution. This corresponds to the experimental data: compared to an uninterrupted problem-solving process, solution time decreases if the process was interrupted 10 seconds after the beginning of the problem solving (at the beginning of the impasse, as we suppose), but does not change after 20 seconds (when a participant is already trapped into the impasse).

Therefore, according to our research, the CE allows the solver to more effectively overcome the impasse: an additional task overloads the central executive, depletes it and leads to the successful solution. When the solution process is interrupted at the right time (in our case - in 10 seconds) it helps to avoid the fixedness and saves extra time on overcoming it.

Considering the efficiency of the interruption outside the impasse we assume that after 20 seconds the solver is no longer in the impasse and the overload of the central executive does not have a facilitating effect on the problem solving.

Summarizing the results, we can conclude that insight problem solving differs from non-insight problem solving but not at each stage of the solution. In addition, it was found that an interruption at some stages has a negative effect on the solution of non-insight problems.

\section{Conclusions}

The CE plays an ambiguous role in solving insight problems. At the impasse, the $\mathrm{CE}$ helps maintain an incorrect primary representation and does not allow the solver to break out of the impasse. Depleting the $\mathrm{CE}$ at this stage enables a more rapid solution of insight problems. The research data allows us to assume that the central executive becomes important again after breaking the impasse. When solving non-insight problems the $\mathrm{CE}$ is not that important at earlier stages of the solution although it is critical at the later stages.

In future experiments we plan to investigate the influence of the $\mathrm{CE}$ on insight and non-insight problem solving during the later stages of finding the solution. The degree of the CE's influence in this period makes it possible to see the subsequent experiment, where the experimental impact will be implemented later than in the present experiment.

\section{References}

Baddeley, A. (2003). Working memory: looking back and looking forward. Nature Reviews. Neuroscience, 4(10), 829-839.

Gilhooly, K. J., Logie, R. H., Wetherick, N. E., \& Wynn, V. (1993). Working memory and strategies in syllogistic-reasoning tasks. Memory and Cognition, 21, 115-124.

Jarosz, A., Colflesh, G., \& Wiley, J. (2010). The effects of alcohol use on creative problem solving. Proceedings of the Annual Meeting of the Cognitive Science Society, 32(32), 563.

Knoblich, G., Ohlsson, S., Haider, H., \& Rhenius, D. (1999). Constraint relaxation and chunk decomposition in insight problem solving. Journal of Experimental Psychology: Learning Memory and Cognition, 25(6), 1534-1555. 
Machinskaya, R. I. (2015). The brain executive systems. Zhurnal Vysshei Neronoi Deiatelnosti imeni I. P. Pavlova, 65(1), 33-60.

Ohlsson, S. (1992). Information-processing explanations of insight and related phenomena. Advances in the Psychology of Thinking, 1, 1-44.

Reverberi, C., Toraldo, A., D’Agostini, S., \& Skrap, M. (2005). Better without (lateral) frontal cortex? Insight problems solved by frontal patients. Brain, 128(12), 2882-2890.

Robbins, T. W., Anderson, E. J., Barker, D. R., Bradley, A. C., Fearnyhough, C., Henson, R., ... Baddeley, A. D. (1996). Working memory in chess. Memory and Cognition, 24(1), 83-93.

Wong, T. J. (2009). Capturing "Aha!" moments of puzzle problems using pupillary responses and blinks (PhD thesis). University of Pittsburgh, Pittsburg, PA, USA.

Polina N. Markina - Ph.D. student, Demidov Yaroslavl State University; junior research fellow, Institute of Psychology, Russian Academy of Sciences.

Research area: cognitive psychology.

E-mail: alxetar@gmail.com

Ilya Yu. Vladimirov - associate professor, Demidov Yaroslavl State University, Ph.D.

Research area: cognitive psychology.

E-mail: kein17@mail.com

\section{Роль центрального исполнителя на этапе тупика в решении инсайтных задач}

\section{П.Н. Маркина ${ }^{\mathrm{a}, \mathrm{b}}$, И.Ю. Владимиров}

${ }^{a}$ Ярославский государственный университет им. П.Г. Демидова, 150000, Россия, Ярославль, ул. Советская, Ә. 14

${ }^{\text {b} Ф Г Б У Н ~ « И н с т и т у т ~ п с и х о л о г и и ~ Р А Н », ~ 129366, ~ М о с к в а, ~ у л . ~ Я р о с л а в с к а я, ~ д . ~ 13, ~ к . ~} 1$

\section{Резюме}

В статье рассматривается роль центрального исполнителя в решении инсайтных и неинсайтных задач. Центральный исполнитель (ЦИ) отвечает за планирование хода действий в задаче, следование плану, сличение наличной ситуации с искомой. Мы предположили, что центральный исполнитель оказывает негативное влияние на решение инсайтных задач на этапе тупика, которое заключается в фиксации решателя на неверной репрезентации. Влияние ЦИ наиболее вредно на этапе тупика, потому что на этом этапе важно отказаться от старых схем решения, разрушить фиксированность и найти новый подход к решаемой задаче. В то время как для решения неинсайтных задач ЦИ нужен на протяжении всего времени решения, потому как для их решения ход действий заранее известен и верно решить задачу можно, просто следуя этому плану. Нарушение работы центрального исполнителя может разрушить последовательность решения неинсайтной задачи, и испытуемый будет вынужден решать задачу заново. В соответствии с этим, мы решили использовать метод дистракции, предполагающий предъявление дополнительной 
задачи во время решения основной. Мы предположили, что центральный исполнитель не сможет обрабатывать две задачи одновременно, следовательно, мы давали испытуемым вторую задачу, которую они должны были решать параллельно с основной. Результаты нашего исследования позволяют подтвердить, что роль центального исполнителя меняется на протяжении решения инсайтных задач: до и после тупика контроль важен для решения задач. До тупика ЦИ отвечает за осмысление условий задачи, рассмотрение всех доступных вариантов решения; после тупика ЦИ помогает осуществить выбор лучшего ответа из перечня доступных вариантов. Но на этапе тупика центральный исполнитель оказывает негативное влияние на решение; для фасилитации решения инсайтных задач нужно подавить работу ЦИ на этом этапе, чтобы дать решателю возможность рассмотреть иррелевантные изначальной репрезентации элементы задачи.

Ключевые слова: инсайт, инсайтное решение, тупик, центральный исполнитель.

Маркина Полина Николаевна - аспирант, Ярославский государственный университет им. П.Г. Демидова; младший научный сотрудник, Институт психологии РАН.

Сфера научных интересов: когнитивная психология.

Контакты: alxetar@gmail.com

Владимиров Илья Юрьевич - доцент, Ярославский государственный университет им. П.Г. Демидова, кандидат психологических наук.

Сфера научных интересов: когнитивная психология.

Контакты: kein17@mail.ru 